\title{
The physiochemical properties of kefir using honey concentrations
}

\section{Andi Padauleng Meliani Anwar ${ }^{1}$, Fatma Maruddin ${ }^{1 *}$, Farida Nur Yuliati ${ }^{1}$, Jamyang Tashi Wangdi ${ }^{2}$ and Muhammad Ihsan Andi Dagong ${ }^{1}$}

\author{
${ }^{1}$ Animal Science Faculty of Hasanuddin University, Jalan Perintis Kemerdekaan Km. 10 \\ Tamalanrea, Makassar 90245, South Sulawesi, Indonesia \\ ${ }^{2}$ Department of Livestock, Ministry of Agriculture and Forests, Royal Government of \\ Bhutan, Bhutan
}

\begin{abstract}
Kefir has a sour taste and distinctive aroma. This condition affects the level of consumer acceptance. The level of consumer acceptance of kefir can be improved by adding a sweetener, namely honey. This study was aimed to determine the characteristics of kefir made from commercial liquid milk to total lactic acid, $\mathrm{pH}$ value, viscosity, organoleptic (taste and preference) panelists to kefir with the addition of honey. This study used a completely randomized design (CRD). The treatment in this study included 4 honey concentrations $(5 \%, 7 \%, 9 \%$ and no added honey as a control, and was repeated thrice. Honey addition in Kefir was made in the following ways: the liquid milk was sterilized at $105^{\circ} \mathrm{C}$ for 5 minutes and sterile milk was cooled down to a temperature of about $40^{\circ} \mathrm{C}$. After cooling, the sterile milk was inoculated with $3 \%(\mathrm{v} / \mathrm{v})$ pre-propagated kefir starter and incubated at $37^{\circ} \mathrm{C}$ for 24 hours. Furthermore, kefir was added with honey treatment with different concentrations and homogenized. Kefir honey was tested for different parameters like total lactic acid, acidity $(\mathrm{pH})$, viscosity, organoleptic (taste and preference). The results showed that the different use of honey kefir did not change the lactic acid content. Increasing use of honey concentration causes $\mathrm{pH}$ value, viscosity, sweetness, and preference to increase. The optimal concentration of honey in making kefir was $9 \%$.
\end{abstract}

\section{Article History}

Received January 26, 2021

Accepted June 22, 2021

\section{Keyword}

Kefir,

Honey concentration,

Viscosity,

Organoleptic.

\section{Introduction}

Kefir is milk that is fermented by a variety of microorganism (bacteria and yeast). Kefir has a taste of sour yeast and thick consistency. The raw material for making kefir is cow or goat milk $(1,2)$. Commercially availableliquid milk can also be used which is easier to obtain and reduces the risk of contamination (3). Kefir has a sour taste, which makes it less attractive to the consumers. Consumer's perception of kefir can be enhanced by adding sweeteners, which are expected to neutralize the sour taste. The sweeteners commonly added to fermented food products are sucrose (4), high fructose syrup (HFS) (5), and honey (6).

Honey is a liquid produced by bees (Apis mellifera). Honey is a solution with high osmolarity and the main constituents in it are monosaccharides $75-80 \%$ (fructose $38.2 \%$

\footnotetext{
* Correspondence : Fatma Maruddin B fatma_maruddin@yahoo.co.id
} 
and glucose $31.3 \%$ ), disaccharides ( $1.31 \%$ sucrose, $7.11 \%$ lactose, and $7.31 \%$ maltose), and water (15 - 23\%) (7). The freshness of honey is determined by the $\mathrm{pH}$ betweeb 3.4 to 6.1 (8). Honey has many benefits and uses for humans. For an example, it has antibacterial and antioxidant properties. The antibacterial efficacy of honey comes from the fact that honey contains flavonoids and has an antibacterial mechanism composed of honey's osmotic pressure, acidity, and the presence of inhibitory compounds (9).

The use of honey in kefir will result in reduced sourness and increased thickness. Honey contains the simple carbohydrates such as glucose and fructose. Both simple carbohydrates have active free hydroxyl groups. The active hydroxyl group reacts with the content of kefir acid to form an ester compound and water. The reaction results in a reduction in the total amount of acid. The increase in kefir viscosity is due to the ability of honey to bind water. This condition will affect the chemical properties of the finished kefir. The change in the product properties can be indirectly recognized by the consumers through change in tastes (sensory evaluation panelists were identified in this study). Therefore, the purpose of this study was to evaluate the characteristics of commercial liquid milk kefir with added honey in terms of total lactic acid, $\mathrm{pH}$, viscosity, and organoleptic preferences (tastes).

\section{Materials and Methods}

This study used a completely randomized design (CRD) $(4 \times 3)$ and the following treatments - no added honey or $0 \%(A 1), 5 \%$ added honey (A2), $7 \%$ added honey (A3), and 9\% added honey (A4). Each treatment was repeated three times. Kefir was produced by adding various concentrations of honey to commercial liquid milk. Commercial kefir seeds were propagated at $3 \%$ concentration into the sterile milk, and then incubated at $37^{\circ} \mathrm{C}$ for 24 hours. Propagation was carried out twice before using it as a starter in making kefir (modified from the method of Sulmiyati et al. (2018) (2).

The Liquid milk was sterilized at $105^{\circ} \mathrm{C}$ for 5 minutes, and then the sterilized milk was cooled to a temperature of of about $40^{\circ} \mathrm{C}$. After cooling, the sterilized milk was inoculated with $3 \%(\mathrm{v} / \mathrm{v})$ pre-propagated kefir starter and incubated at $37^{\circ} \mathrm{C}$ for 24 hours. In addition, kefir treated with honey was added at concentrations of $5 \%, 7 \%$ and $9 \%(\mathrm{v} / \mathrm{v})$ and homogenized. Several tests were carried out with honey kefir, including the determination of total lactic acid, acidity $(\mathrm{pH})$, viscosity, sensory properites (taste) and hedonic properties (modified from the method of Sulmiyati et al. (2019) (10) and Wulandari et al. (2017) (6).

The data obtained were processed using variance according to a completely randomized design (CRD) and the differences between treatments were continued with the Duncan test (11).

\section{Results and Discussions}

The analysis result of kefir with honey in terms of lactic acid, $\mathrm{pH}$, viscosity and sensory are as follows:

\subsection{Total lactic acid in Kefir with different honey concentrations}

Compared with kefir with different concentrations of honey $(5 \%, 7 \%$, and $9 \%)$, the total lactic acid (0\%) of kefir without honey showed similar values (Figure 1). The range of this study was $1.97 \%$ to $1.83 \%$, which is consistent with the study of Purnomo and Muslimin (2012) (12), that is, the acidity is between $1.18 \%$ and $2.45 \%$. 
The results of the analysis of variance (Figure 1) showed that the concentration of honey used in the production of kefir had no significant effect on the total lactic acid of kefir $(P>0.05)$. Overall, the results of the study in Figure 1 indicate that an increase in honey concentration will lead to decrease in total lactic acid. This is believed to be due to the reaction of lactic acid in kefir with the active carbohydrate groups / active free hydroxyl groups (glucose and fructose) in honey. This condition can lead to the formation of other organic compounds (ester compounds) and water. This esterification reaction results in a decrease in the total lactic acid. This is consistent with the view of Winarno (2008) (13) that glucose and fructose have active free hydroxyl groups, so when they are in contact lactic acid, an esterification reaction can occur, in which the $\mathrm{H}^{+}$ion group of lactic acid binds to the active free hydroxyl groups of glucose and fructose.

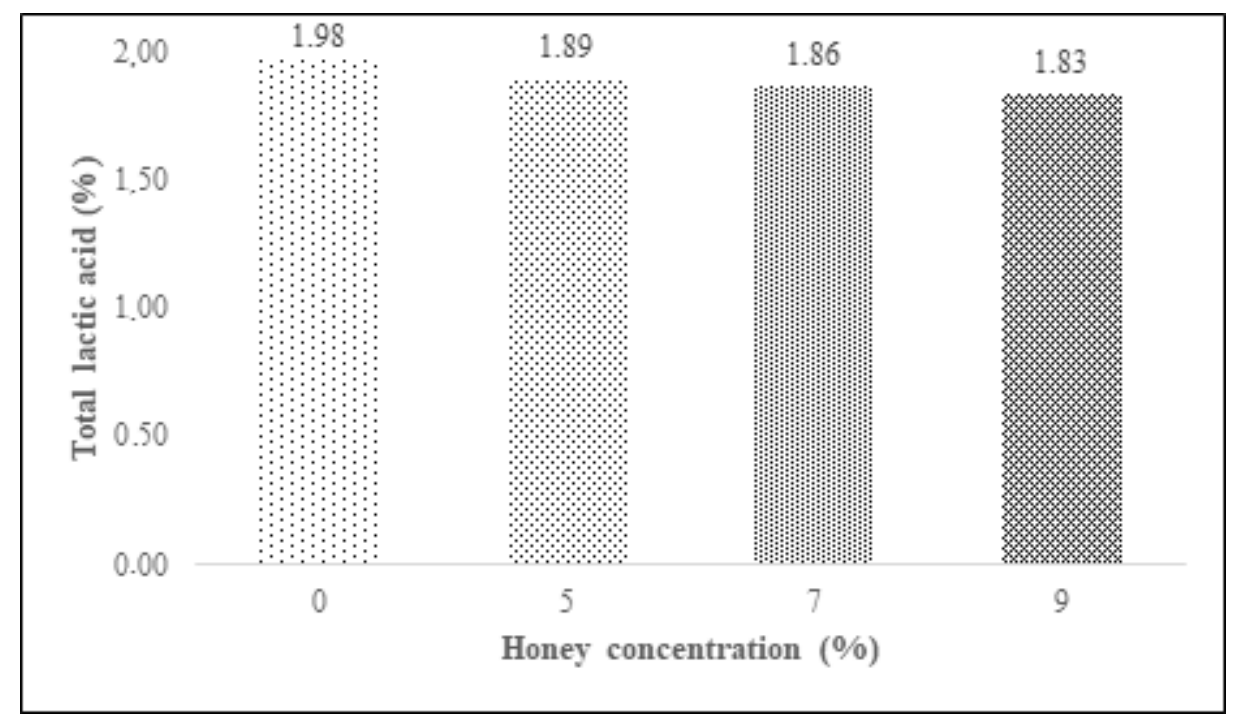

Figure 1. Total kefir lactic acid using honey concentration.

\subsection{Kefir pH value using honey concentration}

The average $\mathrm{pH}$ value of kefir when using different concentrations of honey shows that the $\mathrm{pH}$ value has increased after adding honey by more than $5 \%$. Overall, the $\mathrm{pH}$ range of kefir in this study was 4.3 to 4.50. According to the research of Pamericar et al. (2018) (14) poited out that the normal $\mathrm{pH}$ value of kefir used for the development of bacteria and yeast is around 4.60, which is supported by the findings of of Farnworth (2008) (15), which stated that the $\mathrm{pH}$ value of kefir usually is between $4.20-4.60$.

The analysis result of variance (Figure 2) showed that kefir with the added honey concentration had a significant effect $(\mathrm{P}<0.01)$ on the $\mathrm{pH}$ value of kefir. Duncan's continuous test results showed that kefir with more than $5 \%$ honey exhibited differences. Adding honey above $5 \%$ increases the concentration of active free hydroxyl groups (glucose and fructose); this condition means that more water will be formed at the end of the esterification reaction, so an increase in the number of water molecules leads to increase in $\mathrm{pH}$. This is in agreement with Winarno (2008) (13), who pointed out that glucose and fructose have active free hydroxyl groups. When this group encounters lactic acid, it may experience an esterification reaction in which lactic acid reacts with the hydroxyl groups of glucose and fructose to form ester compounds (other organic compounds) and water. This is supported 
by the opinion of Syaifudin et al. (2015) (16) who stated that the esterification reaction between active free hydroxyl groups and lactic acid will produce water molecules.

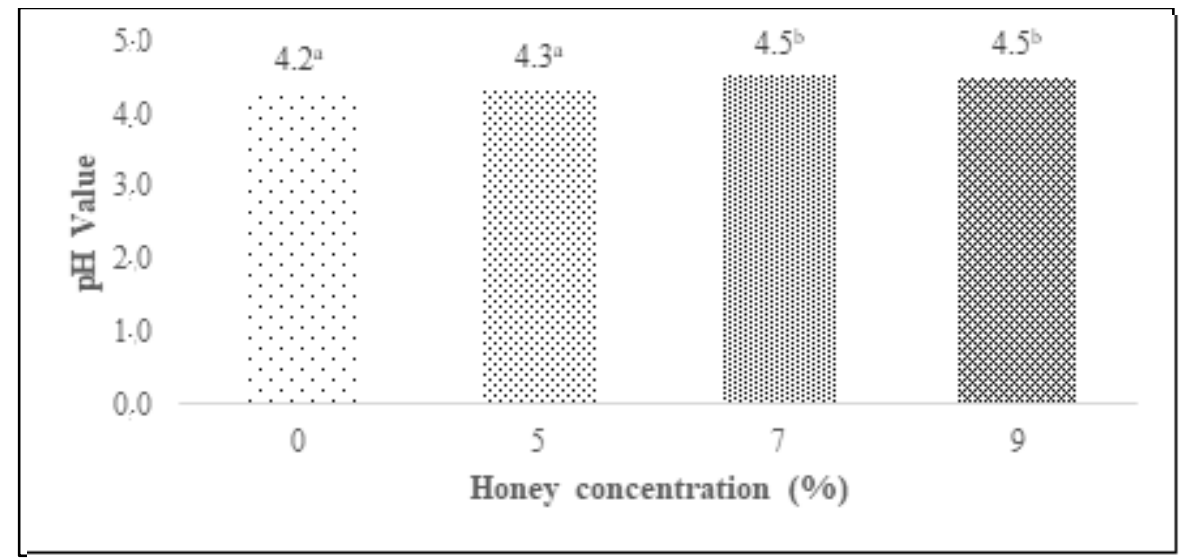

Figure 2. Kefir pH value using honey concentration. Note: Different superscript ${ }^{a, b}$ show very significant differences $(P<0.01)$.

\subsection{Kefir viscosity using honey concentration}

The average viscosity of kefir when using different honey concentrations shows an increase in the viscosity value by more than $5 \%$. In general, the kefir viscosity range in this study was between 0.95 to $2.28 \mathrm{cp}$.

The results of the analysis of variance (Figure 3 ) showed that kefir with the use of different honey concentrations had a very significant effect $(P<0.01)$ on the viscosity of kefir. The results of Duncan's continued test showed that kefir with the addition of honey above $5 \%$ experienced a difference. This is presumably because the use of honey above $5 \%$ has the ability to bind water more efficiently. Honey has a high carbohydrate content so it can bind water. More water will be bound by carbohydrates and the viscosity increases. This is also supported Lau (2013) (17) which states that honey contains very high carbohydrates which are water-binding in nature. This was further supported by Bastanta et al. (2017) (18) who stated that the addition of honey in addition to being used as a sweetener can also be a source of solids which increases the viscosity of a product.

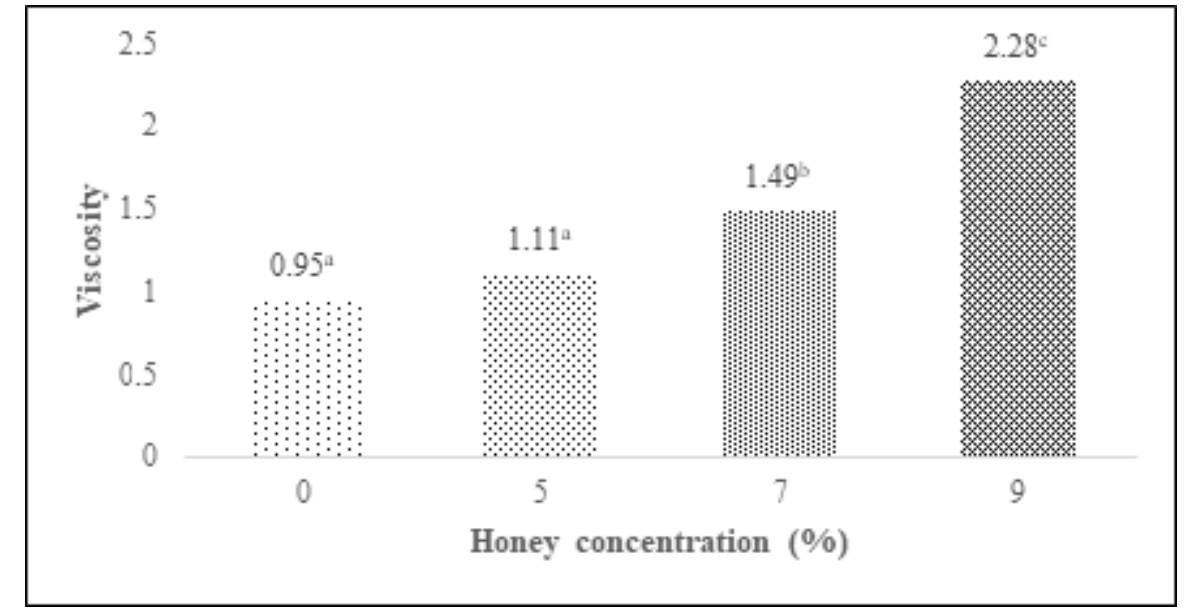

Figure 3. Kefir viscosity using honey concentration. Note : Different superscript ${ }^{a, b}$ show very significant differences $(P<0.01)$. 


\subsection{Organoleptic quality (taste) of kefir using honey concentration}

\subsubsection{Sweetness of kefir}

The sweetness of kefir increased as the concentration of honey was increased (Figure 4). Panelists' assessment of the sweetness of kefir with different addition of honey reached a value ranging from 2.15 to3.75 (less sweet). Meanwhile, the panelists' assessment of kefir without the addition of honey was 1.15 (not sweet). This shows that adding honey to kefir processing makes the final kefir product sweet.

The analysis results of variance (Figure 4) showed that the use of different honey concentrations had a significant effect $(P<0.01)$ on the sweetness of kefir. Duncan's continuous test resulted showed that there were differences in the sweetness of each kefir with added honey. The higher the addition of honey, sweeter the kefir becomes. This is because the honey with carbohydrates in the product act as a sweetener, which is consistent with view of Sapriyanti et al. (2014) (19) whostated that honey is a sweet liquid and can be used as a sweetener in food products. As a sweetener, honey can improve the acceptance of a food by covering the unpleasant taste. This is supported by the opinion of Suranto (2004) (20), who stated that excess honey functions as a sweetener, natural preservative, and contains various vitamins and minerals. Also, Bogdanov et al. (2004) (7) stated that the taste of honey is determined by substances contained in honey, including monosaccharides $75-80 \%$ (fructose $38.2 \%$ and glucose $31.3 \%$ ), disaccharides (1.31\% sucrose, lactose $7.11 \%$, and maltose $7.31 \%)$, and water (15-23\%).

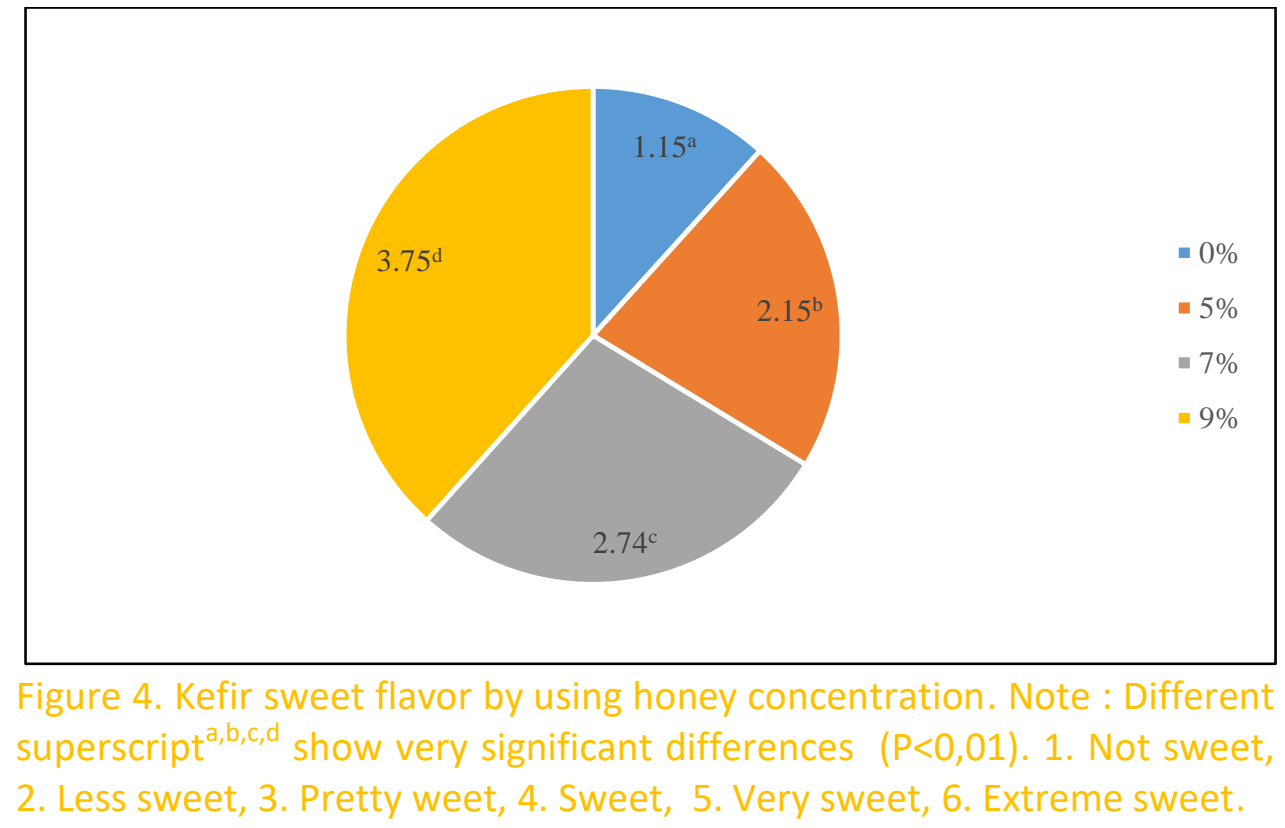

\subsubsection{Sour taste in kefir}

The sourness of kefir decreased as concentration of honey increased (Figure 5). Panelist's assessment of the sourness of kefir with different types honey ranges from 2.78 to 4.02 (very sour-slightly sour), andwith no added honey was 1.54.1.54 (very acidic). This shows that the addition of honey to kefir processing will reduce the sour taste of the final kefir product. 
The results of the analysis of variance (Figure 5) showed that kefir with the use of different concentrations of honey had a significant effect $(P<0.01)$ on the sourness of kefir. The results of Duncan's continued test showed that between each kefir with added honey exhibited a difference in sourness. The higher the concentration of adding honey, the sourness of kefir decreases. This is because adding honey to kefir can reduce the total lactic acid that gives it a sour taste. Kefir lactic acid with the added honey will initiate the esterification process Which leads to lactic acid binding to an active free hydroxyl group in honey, namely glucose and fructose. As a result of the reaction, other organic acid compounds (esters) and water are formed.

According to Winarno (2008) (13), the decrease in lactic acid content is due to the formation of water at the end of the reaction, which leads to a decrease in acidity when honey is added to different concentrations. He found that glucose and fructose have active free hydroxyl groups. When this group encounters lactic acid, an esterification reaction occurs, in which lactic acid reacts with the hydroxyl groups of glucose and fructose to produce ester compounds (other organic compounds) and water. The presence or absence of the reducing properties of sugar molecules is determined by the presence or absence of active free hydroxyl (OH) (glucose and fructose). The active hydroxyl group in glucose is usually at carbon 1 , and the active hydroxyl group in fructose is usually at carbon 2 .

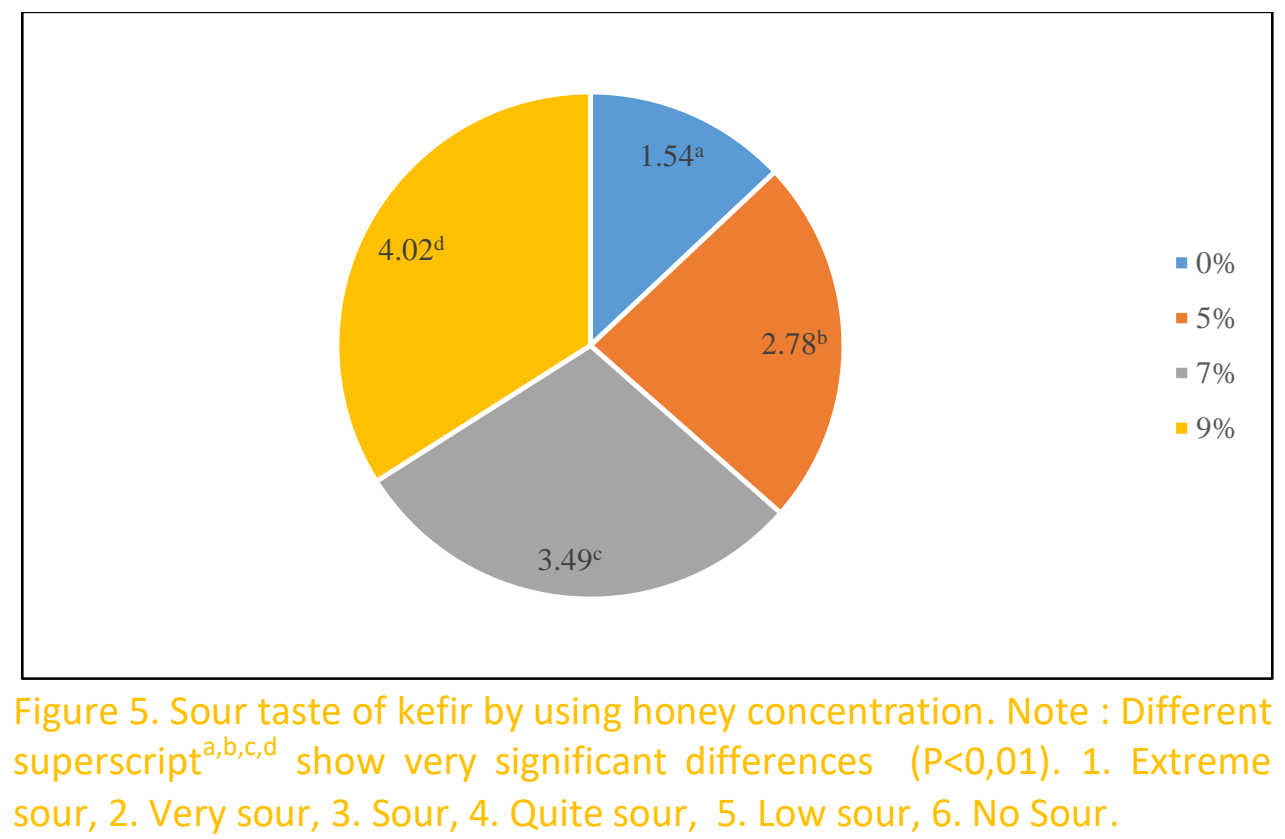

\subsection{Organoleptic quality (favorite) of kefir}

With the use of concentrated honey, the pannelists' preference for concentrated honey kefir increased (Figure 6). The panelists score for the preference of kefir with added honey concentrations reported s value ranging from 2.14 to 3.51 (poor-good). At the same time, kefir without honey was rated as 1.29 by panelists (dislike). This shows that adding honey when processing kefir will increase the preference of panelists for the final product.

Analysis of variance (Figure 7) showed that kefir with the use of honey concentration had a very significant effect $(P<0.01)$ on the preference for kefir products. The results of Duncan's continued test showed that between each kefir with the addition of honey there was a difference in preference level. The higher the honey concentration, the higher the 
panelists' preference. This is due to the increased sweetness of the kefir product and the decrease in sourness along with the increase in honey concentration. This is in accordance with the study of Zuhairah et al. (2019) (21), which stated that honey functions as a natural sweetener that is commonly consumed by humans as a substitute for sugar. As a sweetener, honey can increase the acceptance of a food by covering the unpleasant taste. Apart from that, honey also strengthens food because it balances the bitter, sour and salty taste. Sarwono (2001) (22) stated that forest honey has a distinctive taste, which is sweet with a delicious and fresh aroma. When heated, the aroma becomes stronger but the shape does not change.

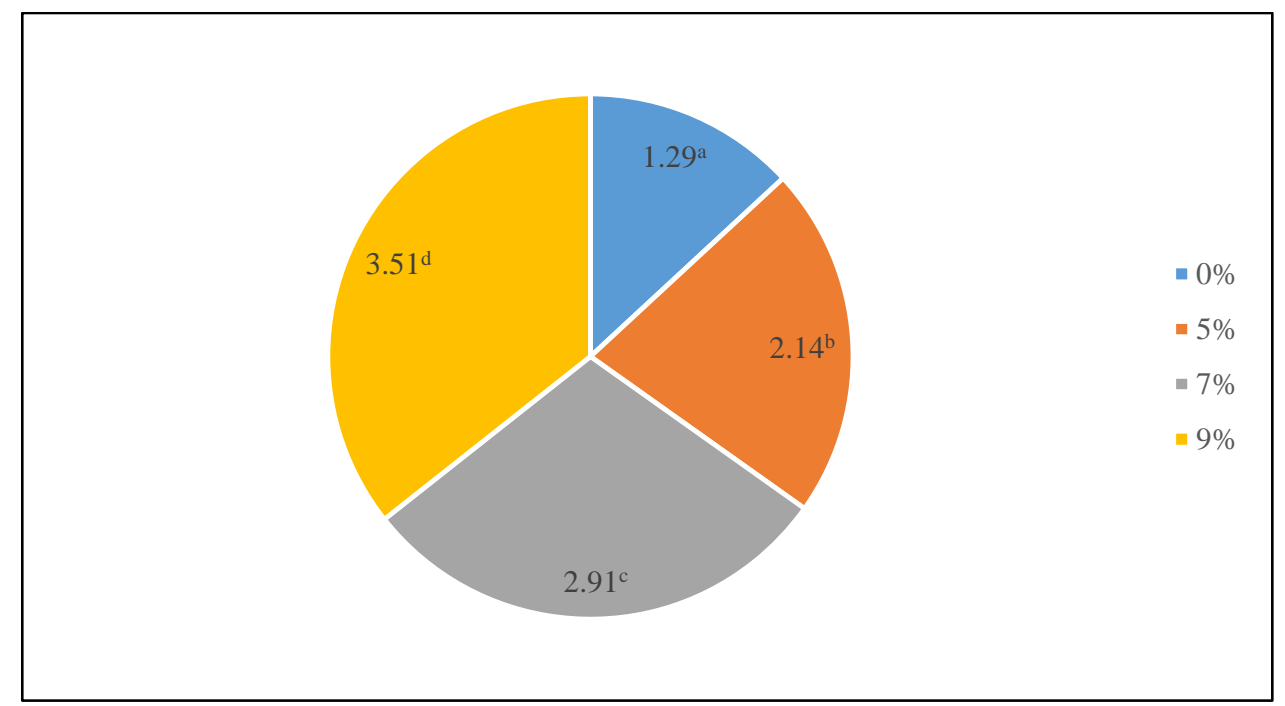

Figure 6. Kefir preference by using honey concentration. Note : Different superscript ${ }^{a, b, c, d}$ show very significant differences $(P<0.01)$. 1. Dislike, 2. Poor, 3. Fair, 4. Good, 5. Very good, 6. Excellent.

\section{Conclusions}

From the results of the research and discussion, it can be concluded that the increasing use of honey in the kefir processing leads to an increase in the characteristics of kefir like $\mathrm{pH}$, sweetness, sourness and preference, but does not change the total lactic acid of kefir. The optimal concentration of honey for kefir is $9 \%$. It is recommended that with further research, the functional properties of use honey to make kefir can be examined.

\section{Acknowledgements}

The authors would thank to the Research and Community Service Institute of Hasanuddin University and Ministry of Research and Technology / BRIN Republic of Indonesia for funding this research through research grant Hibah Terapan 2020.

\section{Author Contributions}

Fatma Maruddin, Muhammad Ihsan Andi Dagong and Farida Nur Yuliaty conceived and design the research and experiments; Andi Padauleng Meliani Anwar performed the experiments in the lab and analysed the data; Muhammad Ihsan Andi Dagong contributed 
reagents and research material; Fatma Maruddin, Andi Padauleng Meliani Anwar and Muhammad Ihsan Andi Dagong wrote the manuscripts.

\section{References}

1. Surono IS. Probiotik, Susu Fermentasi dan Kesehatan. Yayasan Pengusaha Makanan dan Minuman Seluruh Indonesia (YAPMMI). TRICK Jakarta. 2004;

2. Sulmiyati, Said NS, Fahrodi DU, Malaka R, Maruddin F. The characteristics of lactic acid bacteria isolated from Indonesian commercial kefir grain. Malays J Microbiol. 2018;

3. Santoso GJ. Uji formula yoghurt susu UHT (Ultra High Temperature) dengan penambahan daun Katuk (Sauropus androgynus) secara organoleptik. Skrip S. 2016;1.

4. Ali M, Maruddin F, Hatta M. Aktivitas antibakteri, nilai pH dan kadar asam laktat kefir dengan penambahan konsentrasi sukrosa. J Sains Teknol. 2018;18:69-73.

5. Prastiwi VF, Bintoro VP, Rizqiati H. Sifat Mikrobiologi, Nilai Viskositas dan Organoleptik Kefir Optima dengan Penambahan High Fructose Syrup (HFS). J Teknol Pangan. 2018;

6. Wulandari A, Purwadi P, Jaya F. Penambahan madu bunga kopi (Coffea sp.) terhadap kualitas kefir ditinjau dari karakteristik mikrobiologi. J Ilmu dan Teknol Has Ternak. 2017;12(2):83-8.

7. Bogdanov S, Ruoff K, Persano Oddo L. Physico-chemical methods for the characterisation of unifloral honeys: a review. Apidologie. 2004;

8. Gulfraz M, Iftikhar F, Raja S, Asif S, Mehmood S, Anwar Z, et al. Quality assessment and antimicrobial activity of various honey types of Pakistan. African J Biotechnol. 2010;

9. Rio YBP, Djamal A, Asterina A. Perbandingan Efek Antibakteri Madu Asli Sikabu dengan Madu Lubuk Minturun terhadap Escherichia Coli dan Staphylococcus Aureus secara In Vitro. J Kesehat Andalas. 2012;

10. Sulmiyati, Said N, Fahrodi DU, Malaka R, Maruddin F. Assessment of the antibacterial activity of goat milk kefir on Escherichia coli ATCC 8739 and Salmonella enteric subsp. enterica serovar typhimurium ATCC 14028 using a well diffusion method. In: IOP Conference Series: Earth and Environmental Science. 2019.

11. Gaspersz V. Metode perancangan percobaan. Armico Bandung. 1991;427.

12. Purnomo H, Muslimin LD. Chemical characteristics of pasteurised goat milk and goat milk Kefir prepared using different amount of Indonesian Kefir grains and incubation times. Int Food Res J. 2012;

13. Winarno FG. Kimia Pangan dan Gizi: Edisi Terbaru. Jakarta Gramedia Pustaka Utama. 2008;31.

14. Pamericar M, Periadnadi P, Nurmiati N. Existence of Fermentation Microbe in Kefir Etawa Goat Milk. Metamorf J Biol Sci. 5(2):234-7.

15. Farnworth ER. Handbook of fermented functional foods. Handbook of Fermented Functional Foods, Second Edition. 2008.

16. Syaifudin A, Kamulyan B, Mardiana D. Pemanfaatan Nata De Coco Termodifikasi Asam Sitrat Sebagai Bahan Bku Membran. J Ilmu Kim Univ Brawijaya. 2015;1(1):pp-723.

17. Lau E. Heathy Express Super Sehat dalam 2 Minggu. Gramedia Pustaka Utama; 2013.

18. Bastanta D, Karo-Karo T, Rusmarilin H. Pengaruh perbandingan sari sirsak dengan sari 
bit dan konsentrasi gula terhadap sirup sabit. Ilmu dan Teknol Pangan JRekayasa Pangan dan Pert. 2017;

19. Sapriyanti R, Nurhartadi E, Ishartani D. Karakteristik fisikokimiadan sensori velva tomat (Lycopersicum esculentum Mill) dengan pemanis madu. J Teknol Has Pertan. 2014;

20. Adji Suranto S. Khasiat \& manfaat madu herbal. AgroMedia; 2004.

21. Zuhairiah NZT, BR Ginting E, Romatua DG, Fahdi F. Identifikasi kadar glukosa dan sukrosa pada madu hutan. J Penelit Farm Herb. 2019;

22. Sarwono B. Lebah madu. Jakarta Agromedia pustaka. 2001; 